\section{Технологии протезирования}

с использованием ручного труда

\section{ЛЕЧЕНИЕ ПОЛНОЙ ПОТЕРИ ЗУБОВ ВЕРХНЕЙ ЧЕЛЮСТИ С ИЗГОТОВЛЕНИЕМ РЕСТАВРАЦИИ ИЗ ДИОКСИДА ЦИРКОНИЯ С ОПОРОЙ НА ИМПЛАНТАТЫ}

\author{
Dr. Dario Žujić, ZT Velimir Žujić, Rijeka/Хорватия, \\ иnd ZT Dragan Stolica, Maribor/Словения
}

Для обеспечения клинического успеха постоянной конструкции зубного протеза сначала изготавливается временная реставрация длительного пользования в форме мостовидного протеза, которая предназначена для оценки функциональных и эстетических характеристик будущей постоянной протезной конструкции.

Внешние конструкции реставраций с опорой на имплантаты для лечения полной потери зубов можно изготавливать различными способами. В зависимости от состояния костной ткани челюстей и количества установленных имплантатов, для пациента можно изготовить съемную или несъемную реставрацию. С учетом особенностей конкретного клинического случая возможно изготовление несъемной реставрации с фиксацией на цемент или конструкции с прямым винтовым соединением. В описываемом случае планируется изготовить реставрацию из диоксида циркония с фиксацией на цемент. В области жевательных зубов она будет монолитной, а в области передних зубов - доработанной с использованием Cut-back-техники. Для изготовления каркаса мы решили использовать полупрозрачный диоксид циркония Zenostar® T (Wieland Dental), а для облицовки систему IPS $®$ e.max Ceram. Эти материалы одновременно удовлетворяют требованиям к прочности и эстетике.

\section{Исходная ситуация}

Когда пациентка впервые посетила нашу зуботехническую лабораторию, на верхней челюсти был установлен классический полный съемный протез. Женщина была недовольна эстетическим внешним видом, функциональными особенностями и высокой подвижностью протеза. В рамках обследования была проведена DVT (цифровая объемная томография). После обследования установлено наличие достаточного количества костной ткани для фиксации имплантатов. Четыре имплантата позволяют обеспечить хорошую

\section{DT Velimir Žujic}

Privatni zubotenicki laboratorij Velimir Žujic Franje Belulovica 1551000 RijekaCroatia.velimirzujic@yahoo.com velimir@indentalestetica.hr

Dr Dario Žujic

In Dental Estetica dentalni centar Franje Belulovica 15 51000 RijekaCroatia.dario@indentalestetica.hr

\section{TEAMWORK}

\section{Technology meets craftsmanship}

\section{PROSTHETIC IMPLANT RESTORATION OF AN EDENTULOUS UPPER JAW USING ZIRCONIUM OXIDE}

\author{
Dr Dario Žujić, DT Velimir Žujić, both Rijeka/ \\ Croatia, and ŽT Dragan Stolica, Maribor/Slovenia
}

Many edentulous patients wish to have their oral functions re-established with a fixed esthetic restoration. We can meet this request by combining implantology with dental CAD/CAM technology.

Full-arch implant-supported superstructures can be achieved by various methods. Depending on the bone quality and number of implants, the patient may either receive a fixed or removable implant restoration. If a fixed prosthesis is indicated, the superstructure may either be cemented or, alternatively, screwed directly to the implant fixture, depending on the clinical situation. In the case described here, we opted for a cemented zirconium oxide bridge. Monolithic crowns were used in the posterior region. For the anterior region, the crowns were cut back and veneered. Translucent zirconium oxide (Zenostar ${ }^{\circledR}$ T, Wieland Dental) was utilized for the framework and IPS ${ }^{\circledR}$ e.max Ceram for the veneering of the anteriors. These materials allowed the desired strength and esthetics to be achieved.

\section{Preoperative situation}

When the patient came to our dental lab, she wore a classic full-arch denture in her upper jaw. She was unhappy about the esthetic appearance, functional qualities and the loose fit of the denture. Her oral condition was assessed with digital volume tomography (DVT) to confirm that adequate bone quantity was available to facilitate the anchorage of the implants. Although the placement of four implants would have provided adequate stability for a removable denture, the patient desired a fixed all-ceramic reconstruction. Having discussed the treatment options with her, we abandoned the idea of providing an implantsupported denture based on the «All-on-4» concept and instead chose to manufacture a fixed, implant-retained bridge. The framework would be made of zirconium oxide and the anterior teeth would be individually veneered.

\section{Implant treatment and healing phase}

On the basis of the DVT examination, seven implants (Replace CC, Nobel Biocare) were planned and placed. An adequate primary stability of 30 to $35 \mathrm{Ncm}$ was achieved. During the healing phase, the patient wore the existing denture that had been relined with soft silicone. After a six-month healing period, a satisfactory level of osseointegration was achieved, without any signs of bone resorption or inflammation. The implants were 
статику для съемной внешней конструкции, но пациентка пожелала иметь несъемную цельнокерамическую реставрацию. В ходе консультации пациентки было принято решение отказаться от использования концепции «All-on-4».

Запланировано изготовление несъемного мостовидного протеза с опорой на имплантаты. Каркас решено изготовить из диоксида циркония с последующей индивидуальной облицовкой в эстетически значимой видимой области.

\section{Имплантологические мероприятия и этапы лечения}

На основе результатов DVT на верхней челюсти выбрана оптимальная позиция для установки семи имплантатов Replace CC (Nobel Biocare). Все имплантаты после установки продемонстрировали достаточную первичную стабильность в диапазоне 30-35 Нсм. На этапе остеоинтеграции пациентка пользовалась старым протезом, для которого непосредственно в полости рта была изготовлена мягкая силиконовая подкладка. Через шесть месяцев после операции наблюдалась удовлетворительная ситуация без признаков резорбции костной ткани или воспаления. После раскрытия имплантатов на них установили специальные десневые абатменты. Еще через две недели получен оттиск для фиксации позиции имплантатов и передан в лабораторию. После изготовления модели подобраны абатменты, они индивидуализировались таким образом, чтобы обеспечить единое направление сдвига мостовидной внешней конструкции (рис. 1).

Временная реставрация изготовлена с применением цифровых технологий. Модель оцифрована в лабораторном сканере Zenotec ${ }^{\circledR}$ D800 (Wieland Dental), моделирование временного мостовидного протеза проведено с помощью программного обеспечения 3Shape Dental Designer, после чего он отфрезерован на оборудовании Zenotec select S2 (Wieland Dental) из материала на основе ПММА (Telio® CAD).

\section{Изготовление каркаса}

Пациентка осталась полностью удовлетворена формой и функцией временного мостовидного протеза. То есть мы можем использовать его в качестве основы для моделирования постоянной реставрации. При этом необходимо учитывать естественные абразивные фасетки, образовавшиеся в процессе его эксплуатации. 16 В клинике получен оттиск текущей клинической ситуации. В лаборатории отлита и сканирована модель с десневой маской. Сначала оцифровывается рабочая модель с временным мостовидным протезом. Затем проводится сканирование модели с абатментами, модели противоположной челюсти и регистратора окклюзии. В заключение отдельно сканируются абатменты, поскольку в данном случае плечи абатментов располагаются ниже десневого края, и при сканировании на модели эти области невозможно отобразить с необходимой точностью (рис. 2). uncovered and gingiva formers inserted. Two weeks later, an impression was taken to transfer the position of the implants to the dental lab. After model fabrication, appropriate abutments were selected and adapted to achieve a common insert direction for the bridge (Fig. 1).

A long-term temporary bridge was placed to help assess the functional and esthetic requirements that needed to be met to ensure the clinical success of the final restoration.

Digital technology was employed to manufacture the temporary bridge. The model was scanned using a Zenotec ${ }^{\circledR}$ D800 lab scanner (Wieland Dental) and the temporary bridge designed with the 3shape dental design software. Milling was carried out in a Zenotec select S2 milling unit (Wieland Dental) using a PMMA material (Telio ${ }^{\circledR}$ CAD).

\section{Framework fabrication}

As the patient was satisfied with the shape and function of the temporary restoration, we used it as the basis for the design of the final restoration. The natural wear facets that formed during the temporization period should be reflected in the final restoration. A conventional impression of the oral situation was taken in the practice. In the lab, a model and a gingival mask were prepared and scanned. First, the working model together with the temporary bridge was digitized. Next, we scanned the model together with the abutments, the opposing jaw model and the bite registration. Finally, the abutments were scanned individually one after the other because the abutment shoulders were located subgingivally and could therefore not be captured accurately enough with the model scan alone (Figs 2a and $b$ ).

\section{CAD construction}

First, the position of the digitized model was defined in the design software according to the common insert direction of the abutments. In the second step, the shoulder lines of the abutments were marked and the thickness of the cement gap was defined. The shoulder line represents the «preparation margin» of the restoration. In this case, we set the cement gap to $0.2 \mathrm{~mm}$ and the cement space to $0.4 \mathrm{~mm}$. The thickness of the cement gap at the marginal border was set to $0.1 \mathrm{~mm}$. In our experience, these settings

\footnotetext{
Puc. 1. На верхней челюсти необходимо изготовить несъемный мостовидный протез из диоксида циркония с опорой на семь имплантатов

Fig. 1. The seven implants in the edentulous jaw were to be connected to a fixed bridge made of zirconium oxide.
}

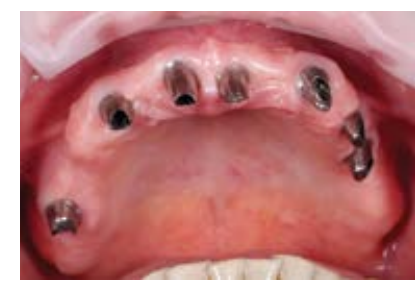




\section{CAD-моделирование}

Сначала в программном обеспечении для моделирования определяется позиция оцифрованной модели по отношению к единому направлению сдвига абатментов. Затем обозначается расположение плечей абатментов, которое отображает положение границы области препарирования реставрации и определяется толщина зазора для цемента. В данном случае мы установили толщину зазора 0,2 мм с расширением до 0,4 мм. Вблизи пришеечной кромки толщина зазора устанавливается 0,1 мм. Практический опыт показывает, что такие параметры обеспечивают великолепную точность фиксации реставрации на модели и в полости рта пациента без трудоемкой дополнительной припасовки. Затем проводится проверка виртуальной модели на соответствие индивидуальным параметрам моделирования. Если в какой-то области толщина конструкции оказывается ниже минимально допустимой для выбранного материала, то программное обеспечение выделяет эту область. Коррекцию выявленных несоответствий можно проводить автоматически или вручную. Моделирование постоянной реставрации осуществляется на основе полностью анатомической структуры временной реставрации длительного ношения. В области зубов с 1.3 по 2.3 полностью анатомическая форма зубов на губной поверхности виртуально препарируется на глубину 0,9 мм, чтобы освободить пространство для частичной облицовки (рис. 3). Структура кромок режущего края оставляется без изменений, поскольку по ним проходят траектории функциональных движений. Сохранение полностью анатомической формы жевательных зубов и небной поверхности передних зубов обеспечивает максимальную прочность реставрации. При изготовлении таких реставраций существует опасность просвечивания абатментов, вследствие чего зубы приобретают безжизненный сероватый оттенок. Поэтому каркас необходимо изготавливать из полупрозрачного диоксида циркония. Имеющейся в данном случае толщины должно быть достаточно для полной маскировки абатментов.

\section{Фрезерование}

Готовая CAD-модель, в которой простой каркас коронки записывается массивом данных из 18000-20000 координат, с гармоничной структурой поверхности и идеальным краевым прилеганием, загружается в управляющий модуль САМ-оборудования. Используемое нами САМ-программное обеспечение версии V3 опционально обрабатывает и выдает данные в различных форматах. Мы предпочитаем работать в формате Zenocam ${ }^{\circledR} 3.2$, который в отличие от открытого формата STL - обеспечивает сохранение и использование информации о выбранной величине зазора для цемента, положении осей имплантатов и форме кромок реставрации. На основе этой информации САМ-программное обеспечение рассчи- result in an excellent accuracy of fit of the restoration on the model and in the patient's mouth, eliminating the need for later adjustments. At the end, the design of the restoration was checked once more against the individual design parameters. If the wall thickness is lower than the minimum acceptable, the software will issue a warning and enable an automated remediation step.

The final restoration was designed using the full-contour long-term temporary as a basis. The full contours of teeth 13 to 23 were reduced by $0.9 \mathrm{~mm}$ on the vestibular aspect to make space for the partial veneers (Figs $3 a$ and $b$ ). The incisal border was left fully contoured as a large number of functional movements occur in this area. The fully contoured shapes of the posterior teeth and the palatal surfaces of the anterior teeth were left unaltered to ensure a maximum level of strength in the final restoration. There was a risk that the abutments might shimmer through as grey areas. For this reason, we decided to use translucent zirconium oxide. The layer thickness appeared to be adequate to mask the abutments.

\section{Milling}

The completed CAD design divides a basic crown framework into 18,000 to 20,000 coordinates and generates a harmonious surface texture and perfect marginal seal. The completed design was transferred to the CAM unit. We use the V3 CAM version, which gives us the option to choose between various output formats. The Zenocam ${ }^{\circledR}$
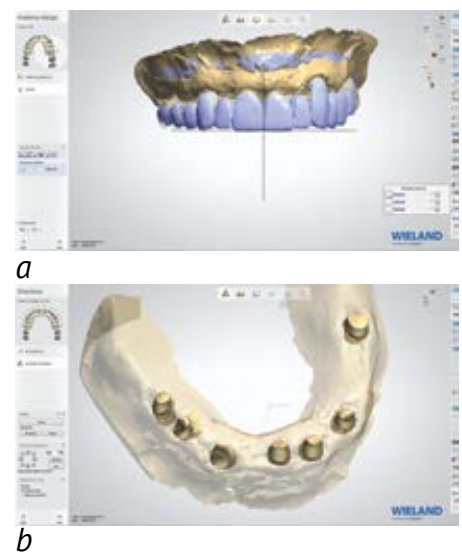

Puc. $2 a$ u $b$. Оцифрованная модель с временной реставрацией и с абатментами Figs $2 a$ and $b$. Digitized model with temporary restorations (above) and abutments (below)

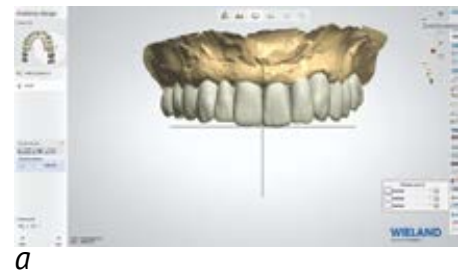

Рuc. $3 a$ и b. Сначала реставрация моделируется в полностью анатомической форме. Затем в эстетически значимой видимой области проводится виртуальная Cut-back Figs $3 a$ and $b$. First, the restoration was designed in full contour and then cut back in the visible esthetic region 
тывает параметры фрезерования, которые отличаются для разных областей реставрации. Благодаря этому, например, при фрезеровании кромок автоматически уменьшается скорость подачи и частота вращения инструмента, что позволяет предотвратить образование трещин и сколов на тонких кромках. Это позволяет сформировать очень тонкие кромки толщиной до 0,1 мм, которые после обжига практически не нужно дорабатывать. Для менее чувствительных областей скорость обработки увеличивается.

Затем выбирается стратегия фрезерования. В данном случае для фрезерования мостовидного протеза мы выбрали стратегию, которая предусматривает применение фрез трех размеров: 2,5; 1 и 0,7 мм. Опциональную возможность применения фрезы размером 0,3 мм мы решили не задействовать, поскольку для таких реставраций это не требуется. На следующем этапе осуществляется позиционирование модели каркаса в виртуальной стандартной заготовке Zenostar®-Disc (рис. 4). Мы решили использовать полупрозрачный диоксид циркония Zenostar T, предварительно окрашенный в цвет T sun, поскольку в области жевательных зубов 14-16 и 24-26 реставрация будет монолитной.

Теплый, слегка красноватый оттенок стандартной заготовки очень близок к выбранному цвету зубов и позволяет эффективно воспроизводить цвета диапазона A - D. После этого моделируется защитная структура, которая обеспечивает размещение реставрации в печи Programat $\AA$ S1 во время обжига в вертикальной позиции. Эта рамка обеспечивает отсутствие деформации при обжиге и высокую точность фиксации протяженных реставраций. Затем осуществляется автоматический расчет программы фрезерования, который занимает всего три минуты.

После этого начинается процесс фрезерования. В данном случае использовалось оборудование Zenotec select S2 со сменным барабаном на 8 дисков (Wieland Dental) и возможностью 5-осевой обработки. Высокая точность фрезерного оборудования обеспечивает достижение великолепного результата фрезерования небной поверхности, поверхности окклюзии и кромок режущего края (рис. 5).

\section{Окрашивание каркаса}

После фрезерования реставрация вместе с защитной структурой для обжига отделяется от стандартной заготовки. На следующем этапе осуществляется индивидуальное окрашивание необожженного мостовидного протеза методом пропитки. Для этого используются специальные жидкие красители Zenostar Color Zr Liquids. Выбирается один из цветов диапазона A-D. Для дополнительной индивидуализации можно использовать пять оттеночных красителей. В данном случае мы использовали жидкие красители Zenostar Color Zr A2, A3 и оттеночный краситель
3.2 format is our preferred output option because, in contrast to the open STL format, it delivers information on the specified cement gap, implant axes and restoration margins. The CAM software uses this information to calculate milling parameters that distinguish between the different areas of the restoration. For instance, when milling the restoration margins, the unit reduces the speed, infeed and feed rate to prevent thin crown margins from breaking or fracturing. As a result, even wafer-thin cervical margins having a thickness of as little as $0.1 \mathrm{~mm}$ can be reliably milled and require only very little reworking after the sintering process. In less sensitive areas, the unit uses a higher milling speed. After the output format has been entered, the milling strategy is chosen. In this case, a milling strategy using $2.5 \mathrm{~mm}, 1.0 \mathrm{~mm}$ and $0.7 \mathrm{~mm}$ burs was selected for the manufacture of the bridge. The option of using a $0.3 \mathrm{~mm}$ bur was not taken as it was not needed for the restoration in question.

Next, the job was placed in a virtual Zenostar $\AA$ blank (Fig. 4). We decided to use a translucent, preshaded Zenostar $\mathrm{T}$ zirconium oxide disc in the shade $\mathrm{T}$ sun, because the posterior teeth from 14 to 16 and 24 to 26 were planned to be restored with monolithic zirconium oxide. The warm, reddish shade of this disc closely matches the selected tooth shade and allows the A - D shades to be recreated efficiently and reproducibly. Next, a sinter support structure was designed to allow the restoration to be sintered in an upright position in the Programat ${ }^{\circledR}$ S1 sintering furnace. The sinter frame minimizes distortion during sintering and is instrumental in achieving a high accuracy of fit in long-span objects. Finally, the program calculated the milling data in a process that took less than three minutes to finish.

Then, the milling operation was started. This process was achieved in a Zenotec select S2 milling unit that features 5-axis operation and an 8-disc material changer (Wieland Dental). The absolute precision with which this unit works is evident in the excellent milling results obtained on the occlusal and palatal surfaces and at the incisal edge (Fig. 5).

\section{Customizing the framework}

Once the milling was completed, the framework and the sinter support structure were separated from the disc. At the next step, the unsintered bridge was customized with colouring liquids using the infiltration technique. The range of Zenostar Color Zr liquids is perfectly suited for this purpose. These liquids are supplied in the standard shades of the A - D shade guide. Additionally, five Effect shades are available for further customizations. We used Zenostar Color Zr in shades A2 and A3 as well as the grey-violet Effect shade. To render the infiltration of the individual liquids visible, the virtually colourless liquids were mixed with a visualizer (Zenostar VisualiZr). First, the interior surfaces of the crowns and the basal surface were infiltrated; followed by approx. $1 \mathrm{~mm}$ of the cervical margin, the fissures and the central areas of the palatal 
grey-violet. Для того чтобы визуализировать процесс окрашивания жидкими красителями, которые наносятся кисточкой, в практически бесцветную жидкость добавляется индикаторный краситель Zenostar VisualiZr (Wieland Dental). Сначала красителем пропитываются внутренняя поверхность коронок и базовая поверх-

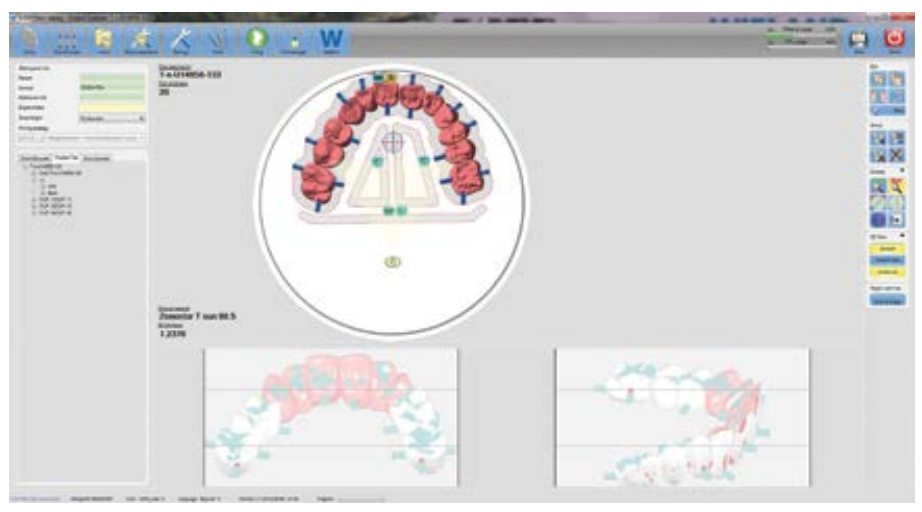
Рис. 4. Размещение модели каркаса мостовидного протеза в виртуальной стандартной заготовке с помощью CAD- программного обеспечения Fig. 4. Nesting of the bridge framework in the CAM software ность; затем область шириной порядка 1 мм вдоль пришеечной кромки, фиссуры и центральная часть небной поверхности. Для этого используется краситель Zenostar Color Zr A 3, подкрашенный желтым индикаторным красителем Zenostar VisualiZr (рис. 6). Затем дентиновая область коронок до резцовой трети окрашивается красителем цвета А 2, подкрашенным красным индикаторным красителем Zenostar VisualiZr. Резцовая область передних зубов и бугорки жевательных зубов окрашиваются оттеночным красителем grey-violet, разбавленным жидкостью Zenotec Optimizer-Liquid. Эта смесь подкрашивается синим индикаторным красителем Zenostar VisualiZr (рис. 7). Важно каждый цвет наносить отдельной кисточкой. После двухэтапной сушки реставрация обжигается в печи Programat S1.

Точность фиксации каркаса после обжига идеальна. Доработка внутренней поверхности коронок не требуется. На этом этапе становятся очевидны эстетические преимущества полупрозрачного диоксида циркония. Благодаря жидким красителям мы подчеркнули пришеечную и дентиновую область каркаса. Серовато-прозрачная область режущего края образует превосходную основу для последующей облицовки. На рис. 8 хорошо видны плавные цветовые переходы. На рис. 9 наглядно показано, насколько сложно было бы воспроизвести нужный цвет зубов при использовании белого опакового диоксида циркония. Кроме того, хорошо видно, что, несмотря на высокую полупрозрачность диоксида циркония, титановые абатменты не просвечивают сквозь каркас.

\section{Индивидуальная доработка каркаса}

Оптимального эстетического результата можно добиться, только если реставрация обладает идеальными оптическими свойствами. Для этого необходимо контролировать уровень яркости, обеспечить достаточную насыщенность цвета, полупрозрачность и минимизировать отражение света. Если эти параметры не соблюдены, то даже после индивидуальной облицовки керамикой можно получить неудовлетворительный результат. В этом случае surfaces. Infiltration of all these aspects was achieved with Zenostar Color Zr A3 mixed with yellow Zenostar VisualiZr (Fig. 6). After that, the dentin area up to the incisal third was infiltrated with shade A2 mixed with red VisualiZr liquid. The incisal area of the anterior teeth and the cusps of the posteriors were customized with a diluted version of grey-violet Effect shade and Zenotec Color Optimizer mixed with blue VisualiZr liquid (Fig. 7). It is essential to use a separate brush for each shade. After having been allowed to dry for two hours, the framework was sintered in a Programat S1 sintering furnace.

After the sintering process, the restoration exhibited an excellent accuracy of fit, without necessitating any adjustments by grinding, e.g. on the insides of the crowns. The advantages of the translucent zirconium oxide used were obvious at this stage. Due to the colouring liquids, the cervical and dentin areas were beautifully accentuated. The incisal areas exhibited a slight greyish-translucent sheen, which should facilitate the subsequent layering procedure. Figure 8 shows the smooth transition of the shades. The simulation in Figure 9 demonstrates how difficult it would have been for us to achieve the desired tooth shade if we had used opaque white zirconium oxide for the framework. Despite the high translucency of the zirconium oxide, the titanium abutments do not show through the framework.

\section{Individual framework refinements}

An optimum esthetic outcome is only achieved if the restoration exhibits ideal optical properties. A controlled brightness value, adequate saturation and translucency and minimized light reflection are essential to achieve a pleasing esthetic outcome. If these parameters are not met, the result will never be satisfactory, even if the restoration is veneered with ceramics. The result would simply be a restoration that looks good on the model but appears too bright in the mouth.

\section{Anterior area}

Staining the zirconium oxide prior to sintering is the first measure to control the light reflection effects. Application of a liner is the second measure. The bridge was veneered with IPS ${ }^{\circledR}$ e.max Ceram. As the framework already exhibited 
реставрации могут хорошо выглядеть на модели, но в полости рта они, как правило, оказываются слишком светлыми.

\section{Область передних зубов}

Первым этапом воспроизведения естественной интенсивности отражения света является окрашивание диоксида циркония перед обжигом. Второй этап - нанесение Liner. Для облицовки мостовидного протеза используется система IPS $®$ e.max Ceram. Каркас уже имеет красивый базовый цвет. На него наносится смесь IPS e.max ZirLiner Clear и Incisal (70:30). ZirLiner Incisal уменьшает отражение света от диоксида циркония; в качестве альтернативы можно использовать Liner 4. Замешивание проводится с помощью IPS e.max ZirLinerBuild-up-Liquid, которая придает смеси благоприятную консистенцию и обеспечивает равномерное нанесение. После обжига формируется гомогенная поверхность с адекватной интенсивностью флуоресценции. При изготовлении крупных реставраций вместо техники рассеивания мы используем технику послойной облицовки на этапе тонкослойного обжига. Техника облицовки (тонкослойный обжиг: Deep Dentin A2, A1 DA2, A1 и T-Neutral) обеспечивает более высокую прочность соединения и лучшие условия взаимодействия со светом (рис. 10). Индивидуальная облицовка вестибулярной поверхности не вызывает никаких проблем. Форма зубов уже определена, и каркас обеспечивает хорошую цветовую основу (облицовка: Dentin A2, A1, T-Neutral, OE1, OE2, I1) (рис. 11). После обжига реставрация демонстрирует запланированную степень яркости, насыщенности света и отражения света.

Цвет реставрации не искажается ни при интенсивном освещении, ни в нормальных условиях, ни при затенении и соответствует выбранному цвету диапазона A-D.

\section{Глазурование монолитной части}

Окрашивание монолитной части (Shades, Stains) проводится еще до обжига дентина. Красители наносятся тонкими «размытыми» слоями. Перед глазуровочным обжигом поверхность покрывается IPS e.max Glaze Fluo.

\section{Финишная обработка реставрации}

После заключительного обжига формируется гармоничная цветовая картина. Качество мостовидного протеза соответствует всем функциональным и эстетическим критериям. Цвет монолитной части не выглядит более светлым, чем цвет облицованной области (рис. 12). В заключение проводятся полирование мостовидного протеза и контроль наличия условий для обеспечения оптимальной гигиены полости рта. Гладкая поверхность является обязательным условием, которое позволяет в полной мере использовать достоинства великолепной био-
Рис. 5. После

фрезерования. высокая

точность обработки

Fig. 5. After milling. high

precision result with

Рис. 6. Окрашивание внутренней поверхности коронок и базовой поверхности

Fig. 6. Shading the interior crown surfaces and

Puc. 7. Окрашенный каркас перед обжигом

Fig. 7. Customized framework prior to sintering excellent marginal accuracy (incisal, occlusal) basal surfaces

Puc. 8. После обжига. плавные цветовые переходы и идеальная цветовая основа для облицовки каркаса Fig. 8. After sintering. smooth colour transition and ideal basic shade for completing the bridge

Рис. 9. Различия между каркасом из Zenostar $\mathrm{Zr}$ и белого опакового диоксида циркония Fig. 9. Comparison between white opaque zirconium oxide (superimposed simulation at the top margin) and the Zenostar Zr framework

a pleasing basic shade, we applied a mixture of IPS e.max Ceram ZirLiner Clear and Incisal (70:30). ZirLiner Incisal reduces the light reflection of zirconium oxide; alternatively Liner 4 may be used. To mix the liners, IPS e.max ZirLiner Build-Up Liquid was added. The result was a mixture with a pleasing consistency, ensuring an even coating. After the firing process, the restoration exhibited a homogeneous surface and an adequate level of fluorescence.

For the foundation firing of large restorations, we prefer the layering technique rather than the sprinkle technique. The layering technique provides better adhesion and optical effects (wash firing: Deep Dentin A2, A1, DA2, A1 and T-Neutral) (Fig. 10). The individual vestibular surfaces can be easily veneered. The tooth shape was given and the framework was used as the basic shade (veneering: Dentin A2, A1, T-Neutral, OE1, OE2, I1) (Fig. 11). After the firing process was completed, the value, saturation and light reflection effects looked as desired. The shade effect of the restoration is identical in intensive light, in normal light and in the shade and matches the chosen A - D tooth shade. 


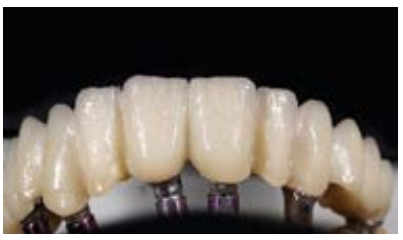

Рис. 10. Вид конструкции после послойного обжига керамики Fig. 10. Appearance of the construction after the layering firing of the ceramic
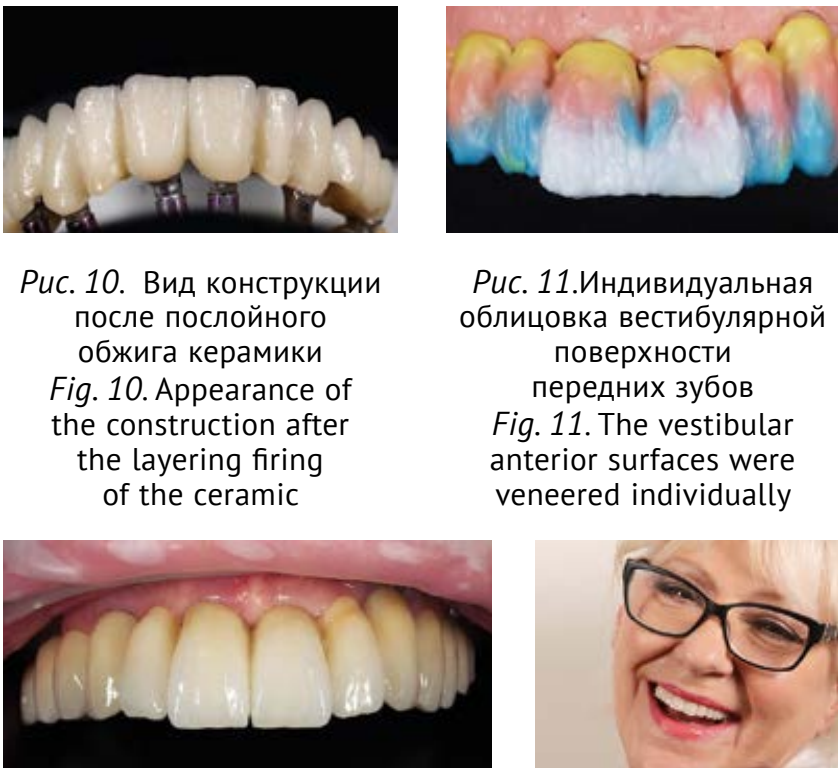

Рис. 11.Индивидуальная облицовка вестибулярной поверхности передних зубов Fig. 11. The vestibular anterior surfaces were veneered individually

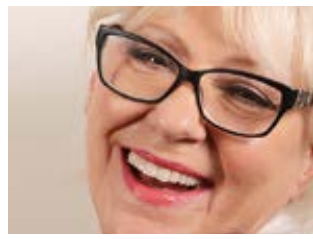

Рис. 14 и 15. Зацементированная мостовидная конструкция радует своей естественностью и отвечает функциональным и эстетическим ожиданиям пациентки.

Figs 14 and 15. The cemented bridge pleases with its beautiful natural appearances and meets the patient's functional and esthetic expectations

совместимости диоксида циркония и предотвратить нежелательный абразивный износ противоположной челюсти. После окончательного контроля реставрация отправляется в клинику (рис. 13).

\section{Резюме}

Фиксация мостовидного протеза на цемент проводится после соответствующей подготовки. Керамическая реставрация в полости рта выглядит объемной. Без какой-либо облицовки в области жевательных зубов наблюдается естественная глубина цвета. Передние зубы производят естественное впечатление живой внутренней игрой цвета и теплой полупрозрачностью (рис. 14). Сочетание современной технологии фрезерования и высококачественной облицовочной керамики обеспечивает эффективность технологического процесса и позволяет добиваться надежного, красивого и долговечного результата. Счастливая пациентка с чудесной естественной улыбкой - прекрасная цель для любой команды, которая занимается протезированием (рис. 15)!

Я благодарю всех своих ассистентов.

https://cloud.mail.ru/public/Gwzx/bQzsuUQ9e

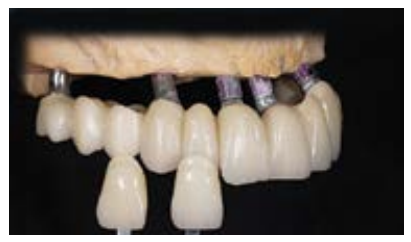

Рис. 12. После

заключительного обжига: цвет монолитной части не выглядит более светлым, чем цвет облицованной области Fig. 12. After final firing: the monolithic crowns did not appear brighter than the veneered crowns

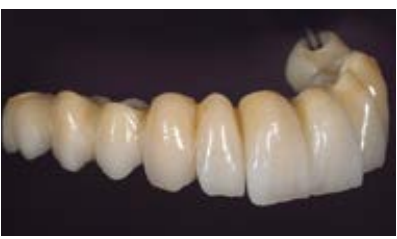

Рис. 13. Готовый мостовидный протез демонстрирует гармоничное распределение цвета и гомогенную поверхность

Fig. 13. Finished bridge:

harmonious shade effects and homogeneous surface texture

\section{Glazing the monolithic areas}

Shade characterizations (Shades, Stains) are applied to the monolithic portions before dentin firing. We continued to apply thin "soft» coatings of colour and used IPS e.max Glaze Fluo for the glaze firing process.

\section{Finishing the restoration}

After the final firing, the restoration exhibited harmonious shade effects. The bridge satisfied all functional and esthetic criteria. The monolithic portions did not appear brighter than the veneered parts (Fig. 12). Finally, we polished the bridge and ensured that the conditions for optimum oral hygiene were in place. Smooth surfaces are essential to prevent the excellent biocompatibility of zirconium oxide from being diminished and undesirable wear from occurring in the opposing jaw. After a final check, the restoration was forwarded to the dental practice (Fig. 13).

\section{Conclusion}

After the preparations were completed, the bridge was cemented in place. The ceramic restoration looks threedimensional. Even without layering, the posterior teeth demonstrate a natural colour depth. With their vibrant internal shade effects and lifelike warm translucency, the anterior teeth demonstrate impressive esthetic properties (Fig. 14). The combination of cutting-edge milling technology and high-quality veneering ceramics provides an efficient route to achieving esthetically pleasing, reliable and long-lasting treatment results. The goal of the prosthetic treatment team is to see a happy patient with a beautiful natural smile (Fig. 15)!

\section{I would like to thank my assistants for their help.}

